\title{
Multi-society Guideline for Reprocessing Flexible Gastrointestinal Endoscopes
}

Douglas B. Nelson, MD; William R. Jarvis, MD; William A. Rutala, PhD; Amy E. Foxx-Orenstein, DO; Gerald Isenberg, MD; Georgia P. Dash, RN, MS, CIC; Carla J. Alvarado, MS, CIC; Marilee Ball, RN, MHA, CGRN; Joyce Griffin-Sobel, RN, PhD, ADCN, APN; Carol Petersen, RN, BSN, MAOM, CNOR; Kay A. Ball, RN, BSN, MSA, CNOR, FAAN; Jerry Henderson; Rachel L. Stricof, MPH

The beneficial role of gastrointestinal endoscopy for the prevention, diagnosis, and treatment of many digestive diseases and cancer is well established. Like many sophisticated medical devices, the endoscope is a complex, reusable instrument that requires reprocessing before being used on subsequent patients. The most commonly used methods for reprocessing endoscopes result in high-level disinfection. To date, all published episodes of pathogen transmission related to gastrointestinal endoscopy have been associated with failure to follow established cleaning and disinfection/sterilization guidelines or use of defective equipment. Despite the strong published data regarding the safety of endoscope reprocessing, concern over the potential for pathogen transmission during endoscopy has raised questions about the best methods for disinfection or sterilization of these devices between patient uses. To this end, the American Society for Gastrointestinal Endoscopy (ASGE) and the Society for Healthcare Epidemiology of America (SHEA) convened a conference at which representatives from physician and nursing organizations, infection control organizations, federal and state agencies, and industry leaders presented and discussed the latest information on this subject. A consensus panel on the second day reviewed the data presented at the conference to recommend evidence-based guidelines for reprocessing gastrointestinal endoscopes.

\section{SPAULDING CLASSIFICATION FOR MEDICAL DEVICES AND LEVEL OF DISINFECTION}

The classification system first proposed by Dr. E. H. Spaulding divides medical devices into categories based on the risk of infection involved with their use. ${ }^{1}$ This classification system is widely accepted and is used by the Food and Drug Administration (FDA), the Centers for Disease Control and Prevention (CDC), epidemiologists, microbiologists, and professional medical organizations to help determine the degree of disinfection or sterilization required for various medical devices. Three categories of

Prevention of Infection During Gastrointestinal Endoscopy Consensus Conference Panel Members: American Society for Gastrointestinal Endoscopy-Douglas B. Nelson, MD, Chair; Society for Healthcare Epidemiology of America-William R. Jarvis, MD, Chair; University of North Carolina Health Care System-William A. Rutala, PhD; American College of Gastroenterology-Amy E. Foxx-Orenstein, DO; American Society of Colon and Rectal Surgeons-Gerald Isenberg, MD; Association for Professionals in Infection Control and Epidemiology-Georgia P. Dash, RN, MS, CIC, and Carla I. Alvarado, MS, CIC; Society of Gastroenterology Nurses and Associates, Inc.-Marilee Ball, RN, MHA, CGRN, and Joyce GriffinSobel, RN, PhD, ADCN, APN; Association of Perioperative Registered Nurses-Carol Petersen. RN, BSN, MAOM, CNOR, and Kay A. Ball, RN, BSN, MSA, CNOR, FAAN; Federated Ambulatory Surgery Association-Jerry Henderson; and New York State Department of Health-Rachel L. Stricof, $M P H$.

This position statement has been endorsed by the American Society for Gastrointestinal Endoscopy, the Society for Healthcare Epidemiology of America, the Joint Commission on Accreditation of Healthcare Organizations, the American College of Gastroenterology, the American Gastroenterological Association, the American Society of Colon and Rectal Surgeons, the Society of American Gastrointestinal Endoscopic Surgeons, the Society of Gastroenterology Nurses and Associates, the Association of Perioperative Registered Nurses, the Association for Professionals in Infection Control and Epidemiology, and the Federated Ambulatory Surgery Association.

Prevention of Infection During Gastrointestinal Endoscopy Consensus Conference Participants: Food and Drug Administration-Mary J. Cornelius, RN, BSN, CGRN, and Cathy D. Nutter; Centers for Disease Control and Prevention-Lynne Sehulster, PhD; Advanced Sterilization Products-Martin S. Favero, PhD, Mike McFerson, and Steve Lau; Amsurg Corp._Cynthia Winker, PhD, and John Trocino; Custom UltrasonicsWalter Bond, MS (independent consultant representing), and Lawrence Muscarella, PhD; Fujinon-Kim Smith; Medivators-R. C. Kippenhan, PhD, Terry Mistalski, Roy Malkin, and Paul Harding; Olympus America-Steve Goldstine, PhD, and David Barlow, PhD; Pentax Precision Instrument Corporation -Keith Nelson; Steris-Gerald McDonnell, PhD, Daniel Subach, PhD, and Terri Antonucci; Vision Sciences-Gerald B. Lichtenberger, PhD; and 3M-Patrick Mach.

The participation of employees of federal government agencies should not be interpreted as endorsement or support of this position statement.

Joint copyright (c) 2003 by the American Society for Gastrointestinal Endoscopy and the Society for Healthcare Epidemiology of America.

This article is being published simultaneously in Infection Control and Hospital Epidemiology and Gastrointestinal Endoscopy. 
medical devices and their associated level of disinfection are recognized:

- Critical: A device that enters normally sterile tissue or the vascular system. Such devices should be sterilized, defined as the destruction of all microbial life. Examples of endoscopic instruments that require sterilization are biopsy forceps and papillotomes.

- Semicritical: A device that comes into contact with intact mucous membranes and does not ordinarily penetrate sterile tissue. These devices (eg, endoscopes) should receive at least high-level disinfection, defined as the destruction of all vegetative microorganisms, mycobacteria, small or nonlipid viruses, medium or lipid viruses, fungal spores, and some, but not all, bacterial spores.

- Noncritical: Devices that do not ordinarily touch the patient or touch only intact skin, such as stethoscopes or patient carts. These items may be cleaned by low-level disinfection.

\section{PATHOGEN TRANSMISSION}

More than 10 million gastrointestinal endoscopic procedures are performed annually in the United States. However, reports of pathogen transmission resulting from these procedures are rare. In the largest review to date, comprising 265 scientific articles published between 1966 and 1992, 281 episodes of pathogen transmission were attributed to gastrointestinal endoscopy. ${ }^{2}$ In each instance, pathogen transmission was associated with a breach in currently accepted cleaning and disinfection guidelines, use of an unacceptable liquid chemical germicide for disinfection, improper drying, or defective equipment. When the ASGE Technology Assessment Committee reviewed the 28 cases in that series that had occurred since the adoption of specific guidelines for cleaning and disinfection between 1988 and 1992, they concluded that the incidence of pathogen transmission was approximately 1 in 1.8 million procedures. ${ }^{3}$

Since 1993, there have been only five additional reported cases of pathogen transmission during gastrointestinal endoscopy, all occurring outside the United States. One instance of Trichosporon esophagitis was caused by failure to sterilize biopsy forceps between patients. ${ }^{4}$ There have been four episodes of transmission of hepatitis $\mathrm{C}$ virus (HCV), and each has been associated with a breach in accepted endoscope reprocessing protocols or a lapse in general infection control practices (inappropriate use of multi-dose vials/bottles and/or reuse of syringes). ${ }^{5-7}$ The importance of good general infection control practices is highlighted by a recent outbreak of $\mathrm{HCV}$ at a New York endoscopy center. Although it was initially attributed to endoscopic transmission in the lay press, investigation by the New York City Department of Health revealed the cause was not the endoscopy itself, but related to improper handling of intravenous sedation tubing or multidose vials and/or reuse of needles (letter on file, New York City Department of Health; unpublished data presented at conference). This aspect of standard infection control practice must also be addressed when future reports of pathogen transmission are published. When the CDC Division of Healthcare Quality Promotion (formerly the Hospital Infection Program) reviewed its $\log$ of investigations between 1980 and 2002, no outbreaks of infection associated with gastrointestinal endoscopy were found. Since 1990, healthcare facilities and manufacturers have been required to report to the FDA any information that reasonably suggests that a device (such as an endoscope, accessory, or automated endoscope washer-disinfector) has caused or contributed to a death, injury, or serious illness of a patient. Review of the FDA Manufacturer And User-Facility Device Experience (MAUDE) database from 1990 to 2002 revealed seven possible episodes of pathogen transmission during gastrointestinal endoscopy. Although there are no welldesigned prospective studies on the incidence of pathogen transmission during gastrointestinal endoscopy, and estimates of pathogen transmission based on case reports may underestimate the true incidence of infection, available evidence suggests that this is an extremely rare event.

\section{GASTROINTESTINAL ENDOSCOPE REPROCESSING}

Flexible gastrointestinal endoscopes should first be cleaned and subjected to at least high-level disinfection. This standard has been recommended by federal agencies such as the $\mathrm{FDA}^{8}$ and $\mathrm{CDC}^{9}$; professional organizations such as the ASGE, the American College of Gastroenterology, the American Gastroenterology Association, the Society of Gastroenterology Nurses and Associates, the Association of Perioperative Registered Nurses, and the Association for Professionals in Infection Control and Epidemiology; and the American Society for Testing and Materials. ${ }^{10-13}$ Guidelines are available from these organizations that discuss, in a stepby-step fashion, the elements of appropriate endoscope reprocessing. ${ }^{10-14}$ There are no published studies of transmission of infection when these guidelines have been followed.

However, compliance with reprocessing guidelines can be improved. In 1991, Gorse and Messner surveyed 2,030 members of the Society of Gastroenterology Nurses and Associates and found that compliance with various aspects of existing guidelines ranged from $67 \%$ to $93 \%{ }^{15}$ That same year, a collaborative study by the FDA and three state health departments investigating endoscope reprocessing at 26 healthcare facilities reported that $24 \%$ of patient-ready endoscopes (gastrointestinal endoscopes and bronchoscopes) were culture positive, and these were associated with "a number of fundamental errors in the disinfection process." 16,17 More concerning, Jackson and Ball surveyed 19 family practice and internal medicine offices performing flexible sigmoidoscopy and found that all were deficient in following reprocessing guidelines in at least one area. ${ }^{18}$ Although two more recent studies suggest that compliance with reprocessing guidelines has improved, ${ }^{19,20}$ a minority of endoscopy centers still did not conform completely to accepted guidelines. Future efforts should be aimed at improving compliance with accepted guidelines in all venues where endoscopy is performed. 


\section{RECOMMENDATIONS (SEE THE APPENDIX FOR A DESCRIPTION OF CATEGORIES)}

Professional organizations vary in recommended practices. The current document is not intended to replace these guidelines, but to complement them, emphasizing those areas in which a broad range of professionals have reached consensus based on the available evidence. Endoscopes employing disposable components (eg, protective barrier devices, sheaths, or valves) can provide an alternative to conventional liquid chemical disinfection. Users should refer to manufacturers' instructions for appropriate reprocessing.

1. All healthcare personnel in the endoscopy suite should be trained in and adhere to standard infection control recommendations (eg, standard precautions), including those to protect both patients and healthcare workers. Category $I A^{9}$

2. Perform pressure/leak testing after each use according to manufacturer guidelines. Category $I B^{11-14,21}$

3. Disconnect and disassemble endoscope components (eg, air/water and suction valves) as far as possible and completely immerse the endoscope and components in the enzymatic detergent. Category $1 B^{21-23}$

4. Cleaning is essential prior to manual or automated disinfection. Meticulously clean the entire endoscope, including valves, channels, connectors, and all detachable parts with an enzymatic detergent compatible with the endoscope immediately after use, according to the manufacturer's instructions. Flush and brush all accessible channels to remove all organic (eg, blood or tissue) and other residues. Repeatedly actuate the valves during cleaning to facilitate access to all surfaces. Clean the external surfaces and components of the endoscope using a soft cloth, a sponge, or brushes. Category $I A^{2,10-14,21,24-33}$

5 . Use brushes appropriate for the size of the endoscope channel, parts, connectors, and orifices (eg, bristles should contact all surfaces) for cleaning. Cleaning items should be disposable or thoroughly cleaned and disinfected/sterilized between uses. Category $I I^{14,21,28,33}$

6. Discard enzymatic detergents after each use, as these products are not microbicidal and will not retard microbial growth. Category $I B^{12,14,21,23}$

7. Reusable endoscopic accessories (eg, biopsy forceps or other cutting instruments) that break the mucosal barrier should be mechanically cleaned as described above and then sterilized between each patient use (high-level disinfection is not appropriate). Category $I A^{2,5,9-14,21,26,28,33,34}$

8. Ultrasonic cleaning of reusable endoscopic accessories and endoscope components may be used to remove soil and organic material from hard to clean areas. Category $I^{21,33}$

9. Endoscopes (and accessories) that come in contact with mucous membranes are classified as semicritical items and should receive at least high-level disinfection after each patient use. Category $I A^{2,9-12,14,21,26,28,33,35}$

10. Use a high-level disinfectant/sterilant cleared by the FDA for high-level disinfection/sterilization (www.fda.gov/cdrh/ode/germlab.html). Category $I A^{2,9,10-12,14,21,26,28,35,36}$
11. The exposure time and temperature for disinfecting semicritical patient care equipment varies among the FDA-cleared high-level disinfectants. Follow the FDAcleared label claim for high-level disinfection unless several well-designed experimental scientific studies, endorsed by professional societies, demonstrate an alternative exposure time is effective for disinfecting semicritical items. The FDA label claim for high-level disinfection with greater than $2 \%$ glutaraldehyde at $25^{\circ} \mathrm{C}$ ranges from 20 to $90 \mathrm{~min}$ utes depending on the product. However, multiple scientific studies and professional organizations support the efficacy of greater than $2 \%$ glutaraldehyde at 20 minutes at $20^{\circ}$ C. Category $I A^{1,10,21,26,27,32,37-49}$

12. Select a disinfectant/sterilant that is compatible with the endoscope. The use of specific high-level disinfectants/sterilants on an endoscope should be avoided if the endoscope manufacturer warns against use because of functional damage (with or without cosmetic damage). Category $I B^{21,50,51}$

13. The selection and use of disinfectants in the healthcare field is dynamic, and products may become available that were not in existence when this guideline was written. As newer disinfectants become available, persons or committees responsible for selecting disinfectants for gastrointestinal endoscope reprocessing should be guided by products cleared by the FDA and information in the scientific literature. Category $I I^{21,26,36}$

14. Completely immerse the endoscope and its components in the high-level disinfectant/sterilant and ensure that all channels are perfused. Nonimmersible gastrointestinal endoscopes should be phased out immediately. Category IB ${ }^{10,11,13,14,21,26,28,52-54}$

15. If an automated endoscope washer-disinfector (AEWD) is used, ensure that the endoscope and endoscope components can be effectively reprocessed in the AEWD (eg, the elevator wire channel of duodenoscopes is not effectively disinfected by most AEWDs and this step must be performed manually). Users should obtain and review model-specific reprocessing protocols from both the endoscope and the AEWD manufacturers and check for compatibility. Category IB $10,12,14,21,28,52-56$

16. If an AEWD is used, place the endoscope and endoscope components in the reprocessor and attach all channel connectors according to the AEWD and endoscope manufacturers' instructions to ensure exposure of all internal surfaces with the high-level disinfectant/chemical sterilant. Category IB ${ }^{14,21,52-54}$

17. If an AEWD cycle is interrupted, high-level disinfection or sterilization cannot be ensured. Category $I I^{14}$

18. Because design flaws have compromised the effectiveness of AEWDs, the infection control staff should routinely review FDA advisories, manufacturer alerts, and the scientific literature for reports of AEWD deficiencies that may lead to infection. Category $I I^{53,57-60}$

19. After high-level disinfection, rinse the endoscope and flush the channels with sterile, filtered, or tap water to remove the disinfectant/sterilant. Discard the rinse water after each use/cycle. Flush the channels with $70 \%$ to $90 \%$ 
ethyl or isopropyl alcohol and dry using forced air. The final drying steps greatly reduce the possibility of recontamination of the endoscope by waterborne microorganisms. Category $I A^{10-13,21,26,30,58,61-63}$

20. When storing the endoscope, hang it in a vertical position to facilitate drying (with caps, valves, and other detachable components removed as per manufacturer instructions). Category II $I^{11,12,14,21,26,28,64}$

21. Endoscopes should be stored in a manner that will protect them from contamination. Category $I I^{11,14,21,26,28}$

22. High-level disinfect or sterilize the water bottle (used for cleaning the lens and irrigation during the procedure) and its connecting tube at least daily. Sterile water should be used to fill the water bottle. Category $I B^{11,21,65-68}$

23. Maintain a log indicating for each procedure the patient's name and medical record number (if available), the procedure, the endoscopist, and the serial number or other identifier of the endoscope (and AEWD, if used) to assist in an outbreak investigation. Category $I I^{11,14,21}$

24. Perform routine testing of the liquid sterilant/high-level disinfectant to ensure minimal effective concentration of the active ingredient. Check the solution at the beginning of each day of use (or more frequently) and document the results. If the chemical indicator shows that the concentration is less than the minimal effective concentration, the solution should be discarded. Category IA ${ }^{10-12,14,21,26,35,42}$

25. Discard the liquid sterilant/high-level disinfectant at the end of its reuse life (which may be single-use), regardless of the minimal effective concentration. If additional liquid sterilant/high-level disinfectant is added to an AEWD (or basin, if manually disinfected), the reuse life should be determined by the first use/activation of the original solution (ie, the practice of "topping off" of a liquid sterilant/high-level disinfectant pool does not extend its reuse life). Category $I B^{14,26,69}$

26. Facilities where endoscopes are used and disinfected should be designed to provide a safe environment for healthcare workers and patients. Air-exchange equipment (eg, ventilation system and exhaust hoods) should be used to minimize the exposure of all persons to potentially toxic vapors (eg, glutaraldehyde). The vapor concentration of the chemical sterilant used should not exceed allowable limits (eg, those of the American Conference of Governmental Industrial Hygienists and the Occupational Safety and Health Administration). Although organic vapor respirators appropriate for chemical exposures can provide respiratory protection (eg, in the event of spills), they are not intended for routine use and are not a substitute for adequate ventilation, vapor recovery systems, and work practice controls. Category $I B$ and $I C^{10,11,14,21,70-73}$

27. Personnel assigned to reprocess endoscopes should receive device-specific reprocessing instructions (ie, endoscope and/or AEWD manufacturer, as needed) to ensure proper cleaning and high-level disinfection or sterilization. Competency testing of personnel reprocessing endoscopes should be done on a regular basis (eg, commencement of employment, annually). Temporary person- nel should not be allowed to reprocess endoscopes until competency has been established. Category $I A^{10-12,14,21}$

28. All personnel using chemicals should be educated about the biological and chemical hazards present while performing procedures that use disinfectants. Category $I C^{21,74}$

29. Personal protective equipment (eg, gloves, gowns, eyewear, and respiratory protection devices) should be readily available and should be used, as appropriate, to protect workers from exposure to chemicals, blood, or other potentially infectious material. Category IC $21,74-76$

30. Healthcare facilities should develop protocols to ensure that users can readily identify whether an endoscope is contaminated or is ready for patient use. Category II

31. The use of routine environmental microbiologic testing of endoscopes for quality assurance has not been established. No recommendation. ${ }^{21}$

32. If environmental microbiologic testing is performed, standard microbiologic techniques should be used. Category $I I^{21,77}$

33. In the setting of an outbreak caused by a suspected infectious or chemical etiology, the environmental sampling should be performed according to standard outbreak investigation. Category $1 A^{11,21,78}$

34. Endoscopy-related infections should be reported to: institution.

a) Persons responsible for infection control at the

b) The appropriate public health agency (state or local health department as required by state law or regulation).

c) The FDA (www.fda.gov/medwatch).

d) The CDC.

e) The manufacturer(s) of the endoscope, disinfectant/sterilant, and AEWD (if used) Category IB and IC $C^{10,11,21,79}$

\section{SUMMARY}

Flexible gastrointestinal endoscopy is a valuable diagnostic and therapeutic tool for the care of patients with gastrointestinal and pancreaticobiliary disorders. Compliance with accepted guidelines for the reprocessing of gastrointestinal endoscopes between patients is critical to the safety and success of their use. When these guidelines are followed, pathogen transmission can be effectively prevented. Increased efforts and resources should be directed to improve compliance with these guidelines. Further research in the area of gastrointestinal endoscope reprocessing should be encouraged. The organizations that endorsed this guideline are committed to assisting the FDA and manufacturers in addressing critical infection control issues in gastrointestinal device reprocessing.

\section{REFERENCES}

1. Favero MS, Bond WW. Disinfection of medical and surgical materials. In: Block SS, ed. Disinfection, Sterilization, and Preservation. Philadelphia: Lippincott Williams \& Wilkins; 2001:881-917. 
2. Spach DH, Silverstein FE, Stamm WE. Transmission of infection by gastrointestinal endoscopy and bronchoscopy. Ann Intern Med 1993;118:117-128.

3. Kimmey MB, Burnett DA, Carr-Locke DL, et al. Transmission of infection by gastrointestinal endoscopy. Gastrointest Endosc 1993;36:885-888.

4. Lo Passo C, Pernice I, Celeste A, Perdichizzi G, Todaro-Luck F. Transmission of Trichosporon asahii esophagitis by a contaminated endoscope. Mycoses 2001;44:13-21.

5. Bronowicki J-P, Venard V, Botté C, et al. Patient-to-patient transmission of hepatitis C virus during colonoscopy. N Engl J Med 1997;337:237-240.

6. Le Pogam S, Gondeau A, Bacq Y. Nosocomial transmission of hepatitis C virus. Ann Intern Med 1999;131:794.

7. Tennenbaum R, Colardelle P, Chochon M, Maisonneuve P, Jean F, Andrieu J. Hepatitis C after retrograde cholangiography [in French]. Gastroenterol Clin Biol 1993;17:763-775.

8. Food and Drug Administration. Draft Guidance for the Content of Premarket Notifications for Endoscopes Used in Gastroenterology and Urology. Rockville, MD: National Press Office; 1995.

9. Garner JS, Favero MS. CDC guideline for handwashing and hospital environmental control, 1985. Infect Control 1986;7:231-243.

10. DiMarino AJ Jr, Leung J, Ravich W, et al. Reprocessing of flexible gastrointestinal endoscopes. Gastrointest Endosc 1996;43:540-546.

11. Alvarado CJ, Reichelderfer M. APIC guidelines for infection prevention and control in flexible endoscopy. Am I Infect Control 2000;28:138-155.

12. American Society for Testing and Materials. Standard Practice for Cleaning and Disinfection of Flexible Fiberoptic and Video Endoscopes Used in the Examination of the Hollow Viscera. West Conshohocken, PA: American Society for Testing and Materials; 2000. F1518-00.

13. Association of Perioperative Registered Nurses. Recommended Practices for Use and Care of Endoscopes: 2002 Standards, Recommended Practices, and Guidelines. Denver: Association of Perioperative Registered Nurses; 2002:229-232

14. Society of Gastroenterology Nurses and Associates. Standards of infection control in reprocessing of flexible gastrointestinal endoscopes. Gastroenterology Nursing 2000;23:172-187.

15. Gorse GJ, Messner RL. Infection control practices in gastrointestinal endoscopy in the United States: a national survey. Infect Control Hosp Epidemiol 1991:12:289-296.

16. Kaczmarek RG, Moore RM Jr, John M, et al. Multi-state investigation of the actual disinfection/sterilization of endoscopes in health care facilities. Am J Med 1992;92:257-261.

17. Reynolds CD, Rhinehart E, Dreyer P, Goldman DA. Variability in reprocessing policies and procedures for flexible fiberoptic endoscopes in Massachusetts hospitals. Am I Infect Control 1992;20:283-290.

18. Jackson FW, Ball MD. Correction of deficiencies in flexible fiberoptic sigmoidoscope cleaning and disinfection technique in family practice and internal medicine offices. Arch Fam Med 1997;6:578-582.

19. Cheung RJ, Ortiz D, DiMarino AJ Jr. GI endoscopic reprocessing practices in the United States. Gastrointest Endosc 1999;50:362-368.

20. Muscarella LF. Current instrument reprocessing practices: results of a national survey. Gastroenterology Nursing 2001;24:253-260.

21. Rutala WA, Weber DJ, the Healthcare Infection Control Practices Advisory Committee. Guideline for disinfection and sterilization in healthcare facilities. Am J Infect Control. In preparation.

22. Merritt K, Hitchins VM, Brown SA. Safety and cleaning of medical materials and devices. J Biomed Mater Res 2000;53:131-136.

23. Babb JR, Bradley CR. Endoscope reprocessing: where do we go from here? J Hosp Infect 1995;30:543-551.

24. Hanson PJV, Gor D, Clarke JR, et al. Contamination of endoscopes used in AIDS patients. Lancet 1989;2:86-88.

25. Vesley D, Norlien KG, Nelson B, Ott B, Streifel AJ. Significant factors in the disinfection and sterilization of flexible endoscopes. Am J Infect Control 1992;20:291-300.

26. Rutala WA. APIC guideline for selection and use of disinfectants. Am J Infect Control 1996;24:313-342.

27. Urayama S, Kozarek RA, Sumida S, Raltz S, Merriam L, Pethigal P. Mycobacteria and glutaraldehyde: is high-level disinfection of endoscopes possible? Gastrointest Endosc 1996;43:451-456.

28. British Society of Gastroenterology. Cleaning and disinfection of equipment for gastrointestinal endoscopy: report of a Working Party of the British Society of Gastroenterology Endoscopy Committee. Gut 1998;42:585-593.

29. Chu NS, McAlister D, Antonoplos PA. Natural bioburden levels detected on flexible gastrointestinal endoscopes after clinical use and manual cleaning. Gastrointest Endosc 1998;48:137-142.

30. Cronmiller JR, Nelson DK, Salman G, et al. Antimicrobial efficacy of endoscopic disinfection procedures: a controlled, multifactorial investigation. Gastrointest Endosc 1999;50:152-158.

31. Kovacs BJ, Chen YK, Kettering JD, Aprecio RM, Roy I. High-level disinfection of gastrointestinal endoscopes: are current guidelines adequate?
Am J Gastroenterol 1999;94:1546-1550.

32. Vesley D, Melson J, Patricia S. Microbial bioburden in endoscope reprocessing and an in-use evaluation of the high-level disinfection capabilities of Cidex PA. Gastroenterology Nursing 1999;22:63-68.

33. The European Society of Gastrointestinal Endoscopy. Guidelines on cleaning and disinfection in GI endoscopy. Endoscopy 2000;32:77-83.

34. Graham DY, Osato MS. Disinfection of biopsy forceps and culture of Helicobacter pylori from gastric mucosal biopsies. Am J Gastroenterol 1999;94:1422-1423.

35. Association of Perioperative Registered Nurses. Recommended Practices for High-Level Disinfection: 2002 Standards, Recommended Practices, and Guidelines. Denver: Association of Perioperative Registered Nurses; 2002:211-216.

36. Food and Drug Administration. FDA-Cleared Sterilants and High Level Disinfectants With General Claims for Processing Reusable Medical and Dental Devices 1/30/02. Rockville, MD: National Press Office; 2002. Available at www.fda.gov/cdrh/ode/germlab.html. Accessed December 9, 2002.

37. Collins FM. Kinetics of tuberculocidal response by alkaline glutaraldehyde in solution and on an inert surface. J Appl Bacteriol 1986;61:87-93.

38. Collins FM. Bactericidal activity of alkaline glutaraldehyde solution against a number of atypical mycobacterial species. J Appl Bacteriol 1986;61:247-251

39. Ascenzi JM, Ezzell RJ, Wendt TM. A more accurate method for measurement of tuberculocidal activity of disinfectants. Appl Environ Microbiol 1987;53:2189-2192.

40. Collins FM. Use of membrane filters for measurement of mycobacterial activity of alkaline glutaraldehyde solution. Appl Environ Microbiol 1987;53:737-739

41. Best M, Sattar SA, Springthorpe VS, Kennedy ME. Efficacies of selected disinfectants against Mycobacterium tuberculosis. I Clin Microbiol 1990;28:2234-2239.

42. Cole EC, Rutala WA, Nessen L, Wannamaker NS, Weber DJ. Effect of methodology, dilution, and exposure time on the tuberculocidal activity of glutaraldehyde-based disinfectants. Appl Environ Microbiol 1990;56:1813-1817.

43. Hanson PJV, Gor D, Jeffries DJ, Collins JV. Elimination of high titre HIV from fiberoptic endoscopes. Gut 1990;31:657-659.

44. Hanson PJ, Jeffries DJ, Collins JV. Viral transmission and fibreoptic endoscopy. J Hosp Infect 1991;18:136-140.

45. Rutala WA, Cole EC, Wannamaker NS, Weber DJ. Inactivation of Mycobacterium tuberculosis and Mycobacterium bovis by 14 hospital disinfectants. Am J Med 1991;91(suppl 3B):267S-271S.

46. Hanson PJ, Chadwick MV, Gaya H, Collins JV. A study of glutaraldehyde disinfection of fibreoptic bronchoscopes experimentally contaminated with Mycobacterium tuberculosis. J Hosp Infect 1992;22:137-142.

47. Best M, Springthorpe VS, Sattar SA. Feasibility of a combined carrier test for disinfectants: studies with a mixture of five types of microorganisms. Am J Infect Control 1994;22:152-162.

48. Jackson J, Leggett JE, Wilson D, Gilbert DN. Mycobacterium gordonae in fiberoptic bronchoscopes. Am J Infect Control 1996;24:19-23.

49. Chanzy B, Duc-Bin DL, Rousset B, et al. Effectiveness of a manual disinfection procedure in eliminating hepatitis $\mathrm{C}$ virus from experimentally contaminated endoscopes. Gastrointest Endosc 1999;50:147-151.

50. Fuselier HA Jr, Mason C. Liquid sterilization versus high level disinfection in the urologic office. Urology 1997;50:337-340.

51. Rutala WA, Weber DJ. Disinfection of endoscopes: review of new chemical sterilants used for high-level disinfection. Infect Control Hosp Epidemiol 1999;20:69-76.

52. Rutala WA, Weber DJ. Importance of lumen flow in liquid chemical sterilization. Am J Infect Control 1999;20:458-459.

53. Sorin M, Segal-Maurer S, Urban C, Combest A, Rahal JJ. Nosocomial transmission of imipenem-resistant Pseudomonas aeruginosa following bronchoscopy associated with improper connection to the Steris System 1 processor. Infect Control Hosp Epidemiol 2001;20:514-516.

54. Centers for Disease Control and Prevention. Bronchoscopy-related infections and pseudoinfections: New York, 1996 and 1998. MMWR 1999;48:557-560.

55. Allen JI. Pseudomonas aeruginosa infection during endoscopy: reply. Gastroenterology 1987:93:1451. Letter.

56. Streulens MJ, Rost F, Deplano A, et al. Pseudomonas aeruginosa and Enterobacteriaceae bacteremia after biliary endoscopy: an outbreak investigation using DNA macrorestriction analysis. $A m \mathrm{~J} \mathrm{Med}$ 1993;95:489-498.

57. O'Connor HJ, Babb JR, Ayliffe GAJ. Pseudomonas aeruginosa infection during endoscopy. Gastroenterology 1987;93:1451.

58. Alvarado CJ, Stolz SM, Maki DG. Nosocomial infections from contaminated endoscopes: a flawed automated endoscope washer. An investigation using molecular epidemiology. Am J Med 1991;91(suppl 3B):272S280 S. 
59. Centers for Disease Control and Prevention. Nosocomial infection and pseudoinfection from contaminated endoscopes and bronchoscopes: Wisconsin and Missouri. MMWR 1991;40:675-678.

60. Fraser VJ, Jones M, Murray PR, Medoff G, Zhang Y, Wallace RJ Jr. Contamination of flexible fiberoptic bronchoscopes with Mycobacterium chelonae linked to an automated bronchoscope disinfection machine. Am Rev Respir Dis 1992;145:853-855.

61. Gerding DN, Peterson LR, Vennes JA. Cleaning and disinfection of fiberoptic endoscopes: evaluation of glutaraldehyde exposure time and forced-air drying. Gastroenterology 1982;83:613-618.

62. Allen JI, Allen MOC, Olson MM, et al. Pseudomonas infection of the biliary system resulting from use of a contaminated endoscope. Gastroenterology 1987;92:759-763.

63. Alfa MJ, Sitter DL. In hospital evaluation of contamination of duodenoscopes: a quantitative assessment of the effects of drying. J Hosp Infect 1991;19:89-98.

64. Noy MF, Harrison L, Holmes GKT, Cockel R. The significance of bacterial contamination of fiberoptic endoscopes. J Hosp Infect 1980;1:53-61.

65. Meenhorst PL, Reingold AL, Groothuis D. Water-related nosocomial pneumonia caused by Legionella pneumophila serogroups 1 and $10 . J$ Infect Dis 1985;152:356-364.

66. Wright EP, Collins CH, Yates MD. Mycobacterium xenopi and Mycobacterium kansasii in a hospital water supply. J Hosp Infect 1985;6:175-178.

67. Rutala WA, Weber DJ. Water as a reservoir of nosocomial pathogens. Infect Control Hosp Epidemiol 1997;18:609-616.

68. Wallace RJ Jr, Brown BA, Driffith DE. Nosocomial outbreaks/pseudooutbreaks caused by nontuberculous mycobacteria. Annu Rev Microbiol 1998;52:453-490.

69. Nelson DB, Barkun AN, Block KP, et al. Transmission of infection by gastrointestinal endoscopy. Gastrointest Endosc 2001;54:824-828.

70. Rutala WA, Hamory BH. Expanding role of hospital epidemiology: employee health-chemical exposure in the health care setting. Infect Control Hosp Epidemiol 1989;10:261-266.

71. Occupational Safety and Health Administration. Air contaminants, final rule. 58 Federal Register 35338-35351 (1993).

72. Weber DJ, Rutala WA. Occupational risks associated with the use of selected disinfectants and sterilants. In: Rutala WA, ed. Disinfection, Sterilization, and Antisepsis in Healthcare. Champlain, NY: Polyscience Publications; 1998:211-226.

73. American Conference of Governmental Industrial Hygienists. Threshold Limit Values for Chemical Substances and Physical Agents and Biologic Exposure Indices. Cincinnati: American Conference of Governmental Industrial Hygienists; 2001
74. Occupational Safety and Health Administration: hazard communication standard, 29 CFR 1910.1200.

75. Occupational Safety and Health Administration: occupational exposure to bloodborne pathogens, final rule. 56 Federal Register 64003-64182 (1991).

76. Carr-Locke DL, Conn MI, Faigel DO, et al. Personal protective equipment. Gastrointest Endosc 1999;49:854-857.

77. Bond WW, Hedrick ER. Microbiological culturing of environment and medical-device surfaces. In: Isenberg HD, Gilchrist MJR, eds. Clinical Microbiology Procedures Handbook. Washington, DC: American Society for Microbiology; 1992:11.0.1-11.0.9.

78. Dixon RE. Investigation of endemic and epidemic nosocomial infection data. In: Bennett JL, Brachman P, eds. Hospital Infection, 3rd ed. Boston: Little Brown; 1992:109-135.

79. Food and Drug Administration. Medical device reporting (MDR). Available at www.fda.gov/cdrh/mdr/. Accessed November 20, 2002.

\section{APPENDIX}

The Centers for Disease Control and Prevention system for categorizing recommendations is as follows:

Category IA. Strongly recommended for implementation and strongly supported by well-designed experimental, clinical, or epidemiologic studies.

Category $I B$. Strongly recommended for implementation and supported by some experimental, clinical, or epidemiologic studies and a strong theoretical rationale.

Category IC. Required by state or federal regulations. Because of state differences, readers should not assume that the absence of an IC recommendation implies the absence of state regulations.

Category II. Recommended for implementation and supported by suggestive clinical or epidemiologic studies or theoretical rationale.

No recommendation. Unresolved issue. Practices for which insufficient evidence or no consensus regarding efficacy exists. 